\title{
Internal stresses and magnetic properties of Fe-Co electrolytic coatings
}

\author{
V.O.Proskurina, I.Yu.Yermolenko, S.I.Zyubanova, \\ I.G.Shipkova, B.A.Avramenko, Yu.I.Sachanova \\ National Technical University "Kharkiv Polytechnic Institute", \\ 2 Kyrpychova St., 61002 Kharkiv, Ukraine
}

Received March 21, 2017

\begin{abstract}
Consideration was given to the effect of electrolysis parameters on the composition and the properties of electrolytic iron-cobalt film coatings obtained from citrate electrolytes. The interconnection between the film composition and the film thickness with its internal stresses and magnetic properties has been studied. It was established that Fe60Co40 alloys show the lowest level of internal stresses for the saturation induction of 1.8 to 2.1. Tl.
\end{abstract}

Keywords: coercive force, Fe-Co galvanic alloy, internal stresses, magnetic properties.

Исследовано влияние параметров электролиза на состав и свойства пленочных электролитических покрытий железо-кобальт, полученных из цитратных электролитов. Установлена взаимосвязь между составом и толщиной пленок с их внутренними напряжениями и магнитными свойствами. Обнаружено, что наименьший уровень внутренних напряжений (-50 МПа) достигается в сплавах Fe60Co40 с индукцией насыщения 1.8-2.1 Тл.

Внутрішні напруги і магнітні властивості електролітичних Fe-Co покриттів. В.О.Проскуріна, І.Ю.Єрмоленко, С.І.Зюбанова, І.Г.Шипкова, БА.Авраменко, Ю.І.Сачанова

Досліджено вплив параметрів електролізу на склад і властивості плівкових електролітичних покриттів залізо-кобальт, отриманих з цитратних електролітів. Встановлено взаємозв'язок між складом і товщиною плівок з ї внутрішніми напруженнями $\mathrm{i}$ магнітними властивостями. Виявлено, що найменший рівень внутрішніх напруг (-50 MПа) досягається у сплавах Fe60Co40 з індукцією насичення 1.8-2.1 Тл.

\section{Introduction}

Recently, the developers of microelectromechanical systems (MEMS) that are controlled by electric and magnetic signals focus their attention on electrolytically deposited magnetic materials. A key issue related to the development of data recording and data keeping devices still remains to be the production of magnetic materials with a high saturation induction and a low coercive force [1]. In this connection, the electrochemical methods of deposition are considered to be a competitive alternative to the physical methods of production [2] due to the possibility of flexible process control and monitoring. This enables the formation of coatings of a varying composition and structure, which is a key factor for production of the materials with specified functional properties. In addition, special attention is paid to the Fe-Co alloys that have a high magnetic induction and a high Curie temperature [3]. When selecting appropriate electrolysis parameters, these characteristics can go well together with opportune structure-sensitive properties of the material, in particular a low coercive force and a high magnetic permeability.

A possibility to increase the macrohardness, the wear resistance and the corrosion resistance of coatings when alloying the electrolytic iron with cobalt will considerably extend the field for the use of such 
materials [4, 5]. Many scientific papers delve into the magnetic properties of binary [6-8] and ternary [9-11] iron and cobalt alloys. The research data [12] show that an increase in the cobalt content in the Fe-Co alloy results in a considerable increase of a coefficient of the residual magnetization of coating and the coercive force is actually not changed. The authors [13] noted that an increase in the magnetization saturation and in coercive force values is observed when the morphology of crystalline Fe-Co deposits changes from the dendrite form to the irregular structure form with an increase in the deposition time from 30 to $90 \mathrm{~min}$.

The scientific paper [14] shows that the saturation magnetization of Fe-Co deposits is controlled by the relation of iron and cobalt ions in the solution and in the alloy, respectively. At the same time, the research data of binary Co-Mo alloys show the tendency to the development of soft magnetic properties in the coatings when the crystal structure gradually acquires a spheroidal shape [15]. The coatings that contain molybdenum in amount of 6 to 10 at. $\%$ show lower values of the coercive force in comparison with a pure cobalt at high saturation magnetization values [16]. The authors [17] showed that an increase in the content of tungsten in the $\mathrm{Co}-\mathrm{W}$ coating up to 25 at. $\%$ contributes to a decrease in the size of crystallites. Thereto, an increase in the microhardness is observed with a simultaneous decrease in the coercive force.

It should be noted that internal stresses resulting in the mechanical strain of coatings with the formation of cracks and the material failure is one of the reasons for a decrease in the service characteristics of galvanic alloys. In addition, internal stresses negatively affect the magnetic properties of coatings [18].

In spite of a sufficient amount of scientific papers devoted to the effect of the composition and the structure of iron triad metals on the magnetic properties of coatings the issues related to the influence of synthesis conditions on the internal stresses and magnetic properties of materials require detailed studies.

The aim of this research was to define internal stresses in the coatings at different electrolysis conditions and establish a degree of their influence on the magnetic characteristics of coatings in the thickness range up to $10 \mu \mathrm{m}$.

\section{Experimental}

The Fe-Co-W coatings were formed on a copper substrate M1 from electrolytic bath of composition, mole $/ \mathrm{dm}^{3}: \mathrm{FeSO}_{4} \cdot 7 \mathrm{H}_{2} \mathrm{O}$ $0.2 ; \mathrm{CoSO}_{4} \cdot 7 \mathrm{H}_{2} \mathrm{O}-0.2 ; \mathrm{C}_{6} \mathrm{H}_{5} \mathrm{O}_{7} \mathrm{Na}_{3} \cdot 2 \mathrm{H}_{2} \mathrm{O}-$ 0.4 ; the $\mathrm{pH}$ value was adjusted within the range 5.0-6.0. The acidity of electrolyte was controlled by pH-meter pH-150M with the glass electrode ESL-6307. The electrolyte solutions were prepared using the certified reagents of chemically pure grade on the distilled water. The temperature of the electrolyte was varied within $25-40^{\circ} \mathrm{C}$. Pretreatment of samples surface includes mechanical polishing, polishing, degreasing, chemical etching in a mixture of the $50 \%$ nitric and $50 \%$ sulfuric acids, thorough washing with distilled water and drying.

Electrolysis was performed in the twoelectrode glass cell using radially positioned anodes of stainless steel grade X18H10T. The ratio of the cathode to the anode area was $1: 5$, volume current density was kept at the level $2 \mathrm{~A} \cdot \mathrm{dm}^{-3}$. For deposition of coatings in a galvanostatic regime with the current density i 2-9 A.dm ${ }^{-2}$, stabilized B5-47 power sources were used. The magnetic stirrer with heating of MM-5 was used for mixing intensity and heating of the electrolyte to the required temperature.

The chemical composition of the coatings was determined by X-ray fluorescence method using a portable spectrometer "SPRUT" with a relative standard deviation of $10^{-3}-10^{-2}$. The error at determining the content of the components is \pm 1 wt. \%. To verify the results, the energy-dispersive X-ray spectroscopy was performed using an electron probe micro analyzer Oxford INCA Energy 350 integrated into the SEM system.

The morphology of the deposits was investigated with a scanning electron microscope ZEISS EVO 40 XVP. The patterns were obtained by the registration of secondary electrons (BSE) with the electron beam scanning, which allowed us to study the morphology with a high resolution and contrast.

The current efficiency was determined gravimetrically assuming that the metals in the coating deposition are completely reduced state. The theoretical increase in mass as a result of electrodeposition was calculated according to Faraday's law taking into account the electrochemical equivalent of the alloy.

Internal stresses that occur in electrolytic Fe-Co deposits were defined using the method of flexible cathode along the deflection arrow and the curvature radius that ap- 

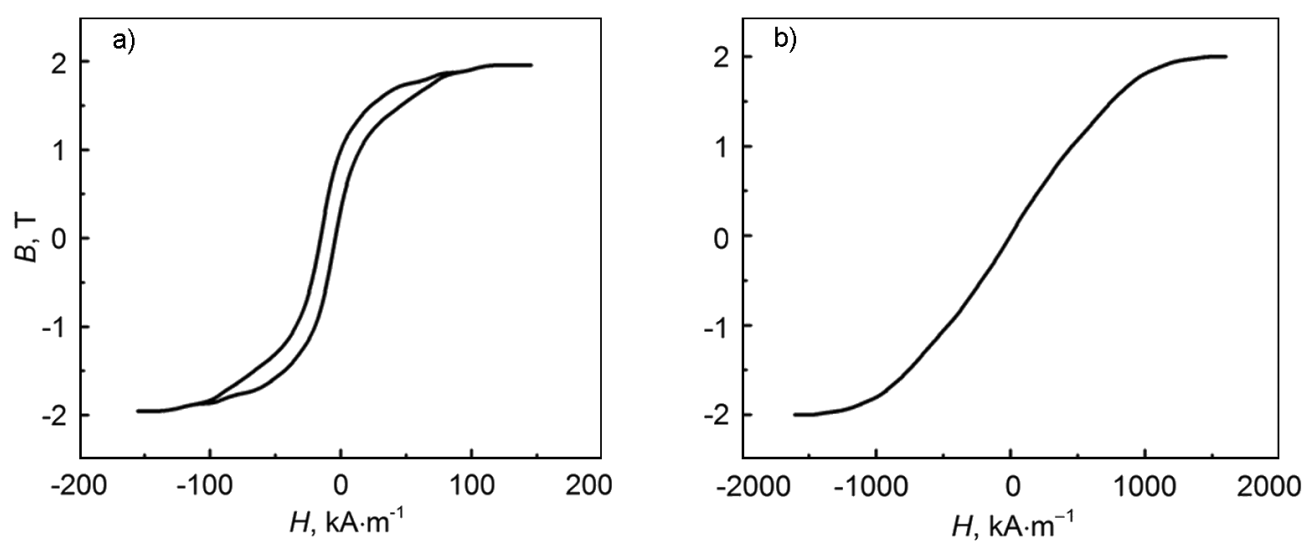

Fig. 1. Hysteresis loops of Fe-Co films measured in fields applied in the plane of the layer (a) and normal to the plane of the layer (b).

pear during the deposition of coating onto the cathode. The cathode deviation was recorded using the device with an inductive sensor.

Magnetic characteristics were measured using the vibration magnetometer for the fields up to $1600 \mathrm{kA} \cdot \mathrm{m}^{-2}$. The coercive force $H_{c}$ and the saturation field $H_{s}$ were defined by hysteresis loops measured in the fields applied to the coating plane (Fig. 1). The saturation magnetization $I_{s}$ and the saturation induction $B_{s}$ were estimated by hysteresis loops obtained for the magnetization of specimens by the film plane normal.

\section{Results and discussion}

Earlier, the authors developed a stable electrolyte for the deposition of Fe-Co [19] coatings that allows for the formation of uniform sediments with a high current output. The research done showed that an increase in the current density results in an increase of the content of iron in the Fe-Co alloy. In the case when the ratio of a sum of the concentrations of complexing agents (Fe and $\mathrm{Co}$ ) to ligand concentration $\left(\mathrm{Cit}^{3-}\right)$ is $1: 1$ it is quite possible to produce more iron than in the case of an increase in the concentration of $\mathrm{Cit}^{3-}$ up to the ratio of $1: 2$ at other equal conditions (Fig.2).

In addition, with an increase in the cathode current density the current efficiency for FeCo alloy coatings is increased to a maximum value of $97 \%$ at $i_{c}=5 \mathrm{~A} \cdot \mathrm{dm}^{-2}$ and afterwards it is decreased (Fig.2). This is explained by the fact that the current potential of a working electrode is shifted to the negative domain with an increase in the current density, therefore the deposition process of a more active component and the hydrogen evolution are intensified (Table 1).

Table 1. Deposition parameters of Fe-Co alloy

\begin{tabular}{||c|c|c|c||}
\hline $\begin{array}{c}\text { Electrolyte } \\
\text { composition, } \\
\text { mole } \cdot \mathrm{dm}^{-3}\end{array}$ & $\begin{array}{c}\text { Current } \\
\text { density } \\
i_{c}, \mathrm{~A} \cdot \mathrm{dm}^{-2}\end{array}$ & $\begin{array}{c}\text { Current } \\
\text { efficiency } \\
\mathrm{Ce}, \%\end{array}$ & $\begin{array}{c}\text { Cathode } \\
\text { potential } \\
E_{c}, \mathrm{~B}\end{array}$ \\
\hline $\mathrm{FeSO}_{4}-0.2$ & 5 & 97 & -1.3 \\
\hline $\mathrm{CoSO}_{4}-0.2$ & 7 & 91 & -1.5 \\
\hline $\mathrm{Na}_{3} \mathrm{Cit}-0.4$ & 10 & 70 & -1.9 \\
\hline $\mathrm{H}_{3} \mathrm{BO}_{3}-0.2$ & 3 & 80 & -1.1 \\
\hline
\end{tabular}

The current density affects the surface morphology and a character of the deposits. At low values of $i_{c}=2 \mathrm{~A} \cdot \mathrm{dm}^{-2}$ the changes in concentration near the cathode have no considerable influence on the process of electrocrystallization and it is evident that the nucleus formation rate yields to that of the crystal growth, therefore the deposits consist of individual large crystallites.

With an increase in the current density up to $i_{c}=5 \mathrm{~A} \cdot \mathrm{dm}^{-2}$ concentration changes near the cathode become so noticeable that it results in an abrupt change in the pattern of electrolysis: the concentration of alloy forming components near the cathode surface is decreased and this, in its turn, results in a greater shift of the cathode potential to the negative side (domain). Thereby, the conditions are created when a rate of the formation of crystallization centers is increased and as a result the sediments with a fine-crystalline structure are formed. A further increase in the current density results in a considerable growth of internal stresses and as a consequence of it in the cracking of coatings. At $i_{c}=9 \mathrm{~A} \cdot \mathrm{dm}^{-2}$ porous $\mathrm{Fe}-\mathrm{Co}$ coatings are deposited with a low current output due to the prevailing hydrogen emission reaction and the alkalization of near-electrode layer. 


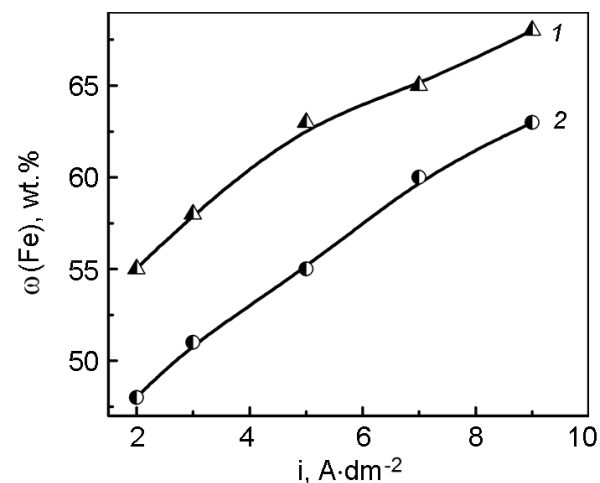

Fig. 2. Effect of current density on the iron content in the Fe-Co alloy ( $(\mathrm{Fe})$, wt. \%) at a concentration ratio of complexing agents: ligand: 1 - 1: $1: 1 ; 2$ - 1: $1: 2 ; \mathrm{pH} 5.5 ; \mathrm{T}=25^{\circ} \mathrm{C}$.

Compression stresses prevail independently of the relation of components and electrolysis modes in the Fe-Co alloy. A level of internal stresses $(\sigma)$ is in the range of 50 to $90 \mathrm{MPa}$ and it is kept in a wide range of cobalt compositions up to 60 wt. \% (Fig.3a). Possibly, this is related to a difference in the crystal lattices of alloy forming metals, in particular when the iron content in the alloy exceeds 50 wt. $\%$ the volume-centered cubic lattice dominates. It has a lower volume in comparison with the hexagonal cobalt lattice.

At the current density of $5 \mathrm{~A} \cdot \mathrm{dm}^{-2}$ the stresses achieve a minimum value of $53 \mathrm{MPa}$, and then these rise to $80 \mathrm{MPa}$ at the current density of $9 \mathrm{~A} \cdot \mathrm{dm}^{-2}$ (Fig. $3 \mathrm{~b}$ ). Such a behavior of the relationship can be explained by an increase in the current output of hydrogen at high current densities, which results in the hydrogenation of coatings. The adsorbed hydrogen releases to a great extent the surface tension, which facilitates the exposure of dislocations on the

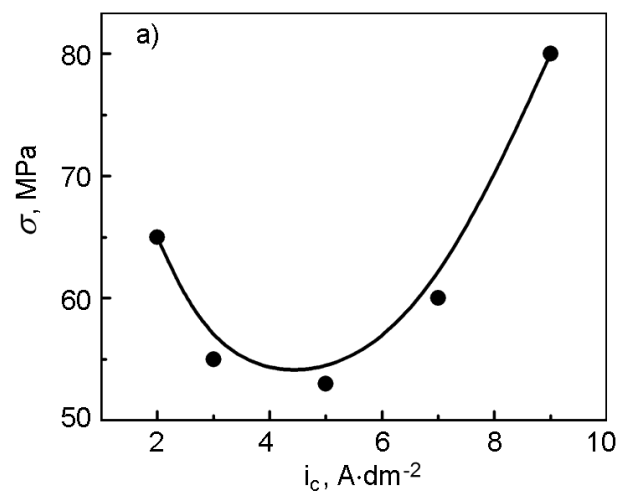

grain surface and results in an increase of internal stresses.

According to the data of scanning electronic microscopy an increase in internal stresses results in the cracking of Fe-Co sediments (Fig.4). At low current densities of $3 \mathrm{~A} \cdot \mathrm{dm}^{-2}$ globular large-crystal sediments were formed ((Fig. 4, a). A surface coated with Fe-Co alloy that was deposited at $i_{c}=5 \mathrm{~A} \cdot \mathrm{dm}^{-2}$ is uniform and fine-crystalline (Fig. 4, b). As the current density is increased to $i_{c}=9 \mathrm{~A} \cdot \mathrm{dm}^{-2}$ a dense net of the cracks appears (Fig. 4, c) due to an increase in internal stresses. It should be noted that vertical cracks prevail (Fig. 4, c) in the coatings and in addition, these reflect the ways of hydrogen emission.

Magnetic characteristics of the coatings of $3 \mu \mathrm{m}$ thick obtained by the analysis of hysteresis loops for the remagnetization of specimens by the field applied to the layer plane are given in Table 2. It has been established that an increase in the cathode current density at $T=25^{\circ} \mathrm{C}$ contributes to an increase in the values of coercive force of the films from $4,4 \mathrm{kA} \cdot \mathrm{dm}^{-1}$ to $6 \mathrm{kA} \cdot \mathrm{dm}^{-1}$. It is rather difficult to establish unambiguously the reason for the growth of such structure-sensitive characteristics as the coercive force, because with an increase in $i_{c}$ the coating morphology and the structure are changed alongside with internal stresses in the system. However, we can assume that the main reason for that is a decrease in the grain size of Fe-Co coatings.

Magnetic properties of Fe-Co coatings deposited at a higher temperature of $40^{\circ} \mathrm{C}$ actually not differ from those of the films obtained at $25^{\circ} \mathrm{C}$, because the factors that predetermine the iron-to-cobalt ratio are the electrolyte composition and the cathode current density. In addition, it should be taken

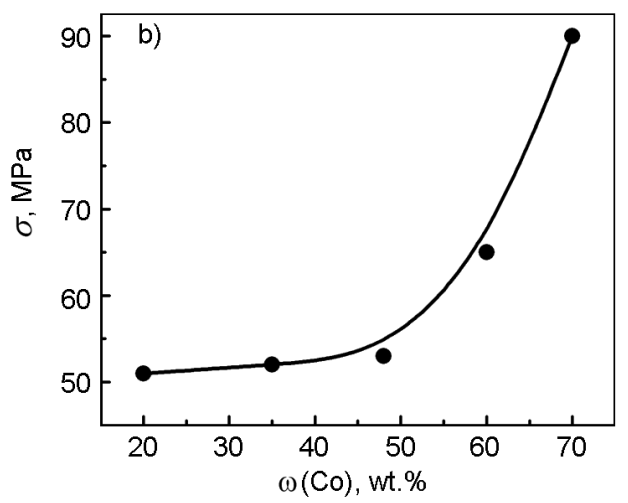

Fig. 3. The influence of the current density (a) and composition of the alloy (b) on the internal stresses of the Fe-Co coating of thickness $2 \mu \mathrm{m} ; \mathrm{pH} 5.5 ; T=25^{\circ} \mathrm{C}$. 


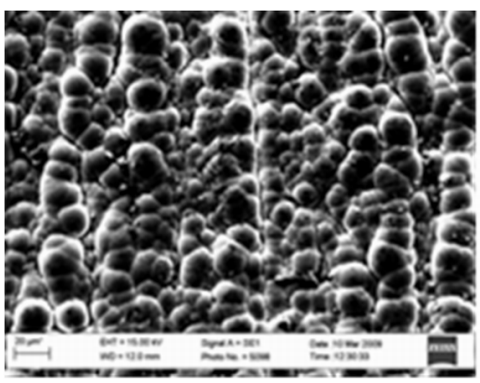

a)

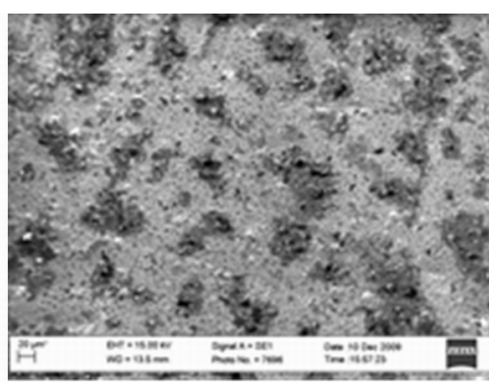

b)

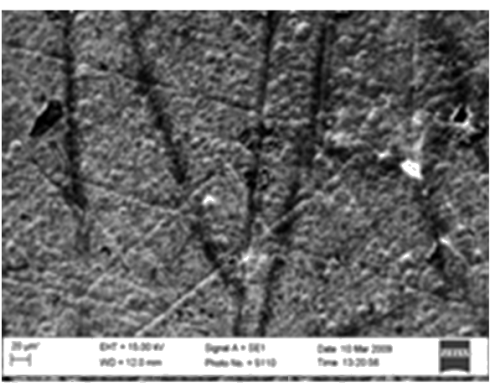

c)

Fig. 4. Topology of the surface of Fe-Co coatings at the current density, A.dm ${ }^{-2}: 3$ (a), 5 (b), 9 (c); $\mathrm{pH} 5.5 ; T=25^{\circ} \mathrm{C}$.

into consideration that a rise in the temperature results in intensification of the oxidation of $\mathrm{Fe}^{2+}$ to $\mathrm{Fe}^{3+}$, and the intermediate compounds formed in the near-electrode layer can be included into the sediment and assumingly this can negatively affect the magnetic properties of coating. Therefore, in increase in the temperature above $40^{\circ} \mathrm{C}$ is undesirable for the deposition of Fe-Co alloy from the citrate electrolyte.

Deposition of coatings with the low values of internal stresses is of great importance at the initial phase of electrolysis, because these conditions provide a qualitative cohesion of the coating and the substrate. In this connection we studied the relationship of internal stresses as a function of the thickness of a deposited layer. The stresses of Fe-Co coatings are slightly decreased (within 10\% only) for all analyzed alloy compositions with an increase in the thickness to $10 \mu \mathrm{m}$. Evidently internal stresses are mainly conditioned by the formation of a new phase on the foreign substrate and are developed in thin films. Later on, the deposition occurs on the newly formed layer of the coating of a similar nature, therefore there is no considerable increase in the stresses.

Magnetic characteristics were measured for the films of a different thickness of the Fe60Co40 alloy, because this composition is deposited at high current output values and has low internal stresses. In addition to the measurements in the field applied to the layer plane, hysteresis loops were measured in strong fields applied to the layer normal. The measurement data are shown in Table 3 .

The data given in Table 3 show that the most essential changes in the coercive force $H_{c}$ are observed at a thickness of $<1 \mu \mathrm{m}$. With an increase in the thickness up to $8 \mu \mathrm{m}$ the values of $H_{c}$ are kept at the level of 6.5 - $7.0 \mathrm{kA} \cdot \mathrm{dm}^{-1}$, and the saturation field $H_{s}$
Table 2. The effect of temperature and current density on the current efficiency and the coercive force $H_{\mathrm{c}}$ of the Fe-Co alloy of thickness $3 \mu \mathrm{m}$

\begin{tabular}{|c|c|c|c||}
\hline $\begin{array}{c}\text { Tempera- } \\
\text { ture T, }\end{array}$ & $\begin{array}{c}\text { Current } \\
\text { density, } i_{\mathrm{c}} \\
\mathrm{A} \cdot \mathrm{dm}^{-2}\end{array}$ & $\begin{array}{c}\text { Current } \\
\text { efficiency } \\
\mathrm{Ce}, \%\end{array}$ & $\begin{array}{c}\text { Coercive } \\
\text { force } \\
H_{\mathrm{c}}, \mathrm{kA} \cdot \mathrm{m}^{-1}\end{array}$ \\
\hline 25 & 3 & 80 & 4.4 \\
\hline 25 & 5 & 97 & 4.8 \\
\hline 25 & 7 & 91 & 6.0 \\
\hline 40 & 5 & 95 & 5.2 \\
\hline
\end{tabular}

is increased to $159 \mathrm{kA} \cdot \mathrm{dm}^{-1}$. The fourth column (Table 3) includes the data that were used for the estimation of magnetization of the Fe40Co60 alloy. It is known [20] that for magnetization of the films to the layer normal it is necessary to overcome the anisotropy field that usually includes the term related to the shape anisotropy (for a flat thin film $H_{k} \perp=N \cdot I_{s}, N=1$ ) and the additional term $\mathrm{Hk}_{\mathrm{s}}$ conditioned by the specific features of the structure or by the availability of stresses in the films. The formula for the calculation of $H_{k} \perp$ in the case of additional strain-magnetostriction anisotropy is expressed as:

$$
H_{k}^{\perp}=N \cdot I_{s}+\frac{3 \lambda \sigma}{\mu_{0} I_{s}},
$$

where $\lambda$ is the magnetostriction constant and $\mu_{0}$ is the magnetic constant.

According to the reference data for the alloys containing 40 to 70 wt. \% of cobalt, the magnetostriction constant is positive and it is in the range of $60 \cdot 10^{-6}$ to $90 \cdot 10^{-6}$ [3]. In this case, the second term in the formula is a negative value and this must result in a decrease of the field $H_{k} \perp$ in comparison with the case when this field is 
Table 3. Influence of coating thickness on magnetic characteristics of Fe60Co40 alloy

\begin{tabular}{||c|c|c|c|c||}
\hline $\begin{array}{c}\text { Thickness of film } \\
\delta, \mu \mathrm{m}\end{array}$ & $\begin{array}{c}\text { Coercive force } H_{\mathrm{c}}, \\
\mathrm{kA} \cdot \mathrm{m}^{-1}\end{array}$ & $\begin{array}{c}\text { Saturation field } \\
H_{\mathrm{s}}, \mathrm{kA} \cdot \mathrm{m}^{-1}\end{array}$ & $\begin{array}{c}\text { The anisotropy } \\
\text { field for } \\
\text { magnetization } \\
\text { along the normal } \\
\text { to the coating } H_{k} \perp \\
\mathrm{kA} \cdot \mathrm{m}^{-1}\end{array}$ & $\begin{array}{c}\text { Induction of } \\
\text { saturation } B_{S}, \mathrm{~T}\end{array}$ \\
\hline 0.1 & 18.0 & - & - & - \\
\hline 0.2 & 12.8 & - & - & - \\
\hline 0.5 & 10.4 & - & 1410 & 1.77 \\
\hline 1.5 & 7.0 & 135 & 1590 & 2.00 \\
\hline 3.0 & 7.2 & 132 & 1690 & 2.12 \\
\hline 4.5 & 7.0 & 149 & 1640 & 2.06 \\
\hline 8.0 & 7.0 & 155 & 1690 & 2.12 \\
\hline
\end{tabular}

only defined by the demagnetization factor $N$ and the film saturation magnetization $I_{S}$. However, the preliminary computations done using the obtained magnetization data showed that the value of $\frac{3 \lambda \sigma}{\mu_{0} I_{s}}$ at the stresses of $\sigma \sim 50 \mathrm{MPa}$ is approximately 300 times lower than that of the first term in the formula (1). Therefore, the saturation magnetization can be derived from the formula $I_{s}=\frac{H_{k}^{\perp}}{N}$. These data are given in the fifth column (Table 3) (the demagnetization factor $N=1$ ). For relatively thick films, saturation induction values are within 1.8-2.1 $\mathrm{Tl}$ that are comparable with metallurgy alloys of the same composition equal to 2.2-2.4 Tl. A lower value of the given parameter for the electrolytic alloy is possibly related to the inclusion of oxide compounds into the coating.

\section{Conclusions}

It has been established that with an increase in the current density Fe-Co alloy coatings are enriched with iron and the grain size is decreased thereat.

It has been shown that for the current density of $5 \mathrm{~A} / \mathrm{dm}^{2}$ and the complexing agents-to-ligand concentration ratio of $1: 1$ the sediments of a Fe60Co40 composition with low internal compression stresses are formed.

It has been established that coatings with an iron content of 60 wt. \% are characterized by a high saturation magnetization of 1.8-2.1 $\mathrm{Tl}$. The coercive force is reduced from $18 \mathrm{kA} \cdot \mathrm{dm}^{-1}$ до $10 \mathrm{kA} \cdot \mathrm{dm}^{-1}$ with an increase in the coating thickness from 0.1 to $0.5 \mu \mathrm{m}$ and in the range of thicknesses of 1.5 to 8.0 it remains actually unchanged and is equal to $7.2-6.5 \mathrm{~A} \cdot \mathrm{dm}^{-1}$.
4. It has been shown that the surface morphology and grain sizes have a key influence on the magnetic characteristics of coatings and the internal stresses are not the deciding factor due to their low level.

\section{References}

1. L.Petera, A.Csikb, K.Vadb, E.Toth-Kadara, A.Pekkera, G.Molnarc, Electrochim. Acta, 55, 4734 (2010). doi: 10.1016/j.electacta.2010. 03.075

2. F.Lallemand, L.Ricq, E.Deschaseaux, L.De Vettor, P.Bercot, Surf. Coat. Technol., 197, 10 (2005).

3. R.Bosart, Ferromagnetism, Inostrannaya literature, Moscow (1956) [in Russian].

4. M.V.Ved', N.D.Sakhnenko, A.V.Karakurchi et al., Zh. Prikl. Chimii, 87(3), 276 (2014). DOI: 10.1134/S1070427214030057

5. P.L.Cavallotti, A.Vicenzo, M.Bestetti, S.Franz, Surf. Coat. Technol., 169-170, 76 (2003).

6. N.Tsyntsaru, H.Cesiulis, M.Donten, J.Sort, E.Pellicer, E.J.Podlaha-Murphy, Surf. Engineering Appl. Electrochem., 48, 491 (2012).

7. E.I.Cooper, C.Bonhote, J.Heidmann et al., IBM J. Res. Develop., 49, 79 (2005).

8. Wei Lu, Ping Huang, Chenchong He and Biao Yan, Int. J. Electrochem. Sci., 7, 12262 (2012).

9. A.V.Karakurkchi, M.V.Ved', N.D.Sakhnenko, et al., Functional Materials, 22, 2 (2015).

10. N.V.Myung, K.Nobe, J. Electrochem. Soc., 148, 3 (2001).

11. N.D.Sakhnenko, M.V.Ved, Yu.K.Hapon, T.A.Nenastina, Zh. Prikl. Chimii, 88(12), 1941 (2015).

12. J.Zarpellon, H.F.Jurca, N.Mattoso et al., J. Colloid Interface Sci., 316, 2 (2007). doi:10.1016/j.jcis.2007.08.032

13. Koay Mei Hyie, Wan Normimi Roslini Abdullah, Nor Azrina Resali et al., J. Nanomaterials, 2013, (2013). http://dx.doi.org/10.1155/ 2013/680491

14. S. Mehrizi, M. Heydarzadeh Sohi, J. Mater. Sci.: Mater. Electron., 26, 7381 (2015). DOI 10.1007/s10854-015-3368-6 
15. E.Gomez, E.Pellicer, X.Alcobe, E.Valles, $J$. Solid State Electrochem., 8, 497 (2004). DOI 10.1007/s10008-004-0495-z

16. E.Gomez, E.Pellicer, E.Valles, J. Electroanal. Chem., 568, 29 (2004). doi:10.1016/j.jelechem. 2003.12.032

17. N.Tsyntsaru, H.Cesiulis, E.Pellicer, J.-P.Celis, J. Sort, Electrochimica Acta, 104, 94 (2013). http://dx.doi.org/10.1016/j.electacta. 2013.0 4.022

18. N.V.Myung, D.-Y.Park, D.E.Urgiles et al., Electrochim. Acta, 49 (2004). doi:10.1016/ j.electacta.2004.04.031

19. Patent. UA 49037 (2010).

20. Technology of Thin Films. Reference book Ed. Maysella, GlengaR.T, V.2: Moscow: Sov.Radio., 768p. (1997) [in Russian]. 